JOURNAL OF SECURITY AND SUSTAINABILITY ISSUES ISSN 2029-7017 print/ISSN 2029-7025 online 2020 March Volume 9 Number 3 https://doi.org/10.9770/jssi.2020.9.3(3)

\title{
SUSTAINABLE DEVELOPMENT FACETS: FACTORS AFFECTING QUALITY OF EDUCATION
}

\author{
Sakapas Saengchai ${ }^{1}$, Sudarat Rodboonsong ${ }^{2 *}$, Samanan Wattanapongphasuk ${ }^{3}$ \\ ${ }^{1}$ Faculty of Humanities and Social Science, Suan Sunandha Rajabhat University, Bangkok, Thailand \\ ${ }^{2}$ Faculty of Humanities and Social Sciences, Uttaradit Rajabhat University, Uttaradit, Thailand \\ ${ }^{3}$ Political Science Association of Kasetsart University, Bangkok, Thailand \\ E-mails: ${ }^{1}$ sakapas.sa@ssru.ac.th; ${ }^{2}$ sudarat_tu@hotmail.com (Corresponding author); \\ ${ }^{3}$ samanan24@gmail.com
}

Received 16 March 2019; accepted 17 December; published 30 June 2020

\begin{abstract}
Education is an inevitable aspect for any country and without it; no country can flourish and grow effectively. Therefore, the quality of education must not be compromised. As the impact of human development, public spending on education and trained teachers' availability is being studied in context of quality of education, a whole study and research plan has been prepared by the author. Data collection process involves the gathering of data from Asian countries for 25 years from reliable data bases. After data collection, several tests and approaches were used for the analysis of data. LLC unit root test was applied for order of integration and stationarity of data, Kao cointegration test was applied to find out cointegrated and long run relationships between the variables and finally DOLS estimation approach was used to measure the relationship between the variables. According to the results of these tests, it has been found that the variables that have significant impact on quality of education include human development, public spending on education, trained teachers' availability and literacy rate. In the last, several theoretical, practical and policy making implications have been discussed by the author. Different limitations have also been identified and future research recommendations have also been given for the assistance of other researchers.
\end{abstract}

Keywords: quality of education; human development; public spending on education; trained teachers' availability; Asia

Reference to this paper should be made as follows: Saengchai, S., Rodboonsong, S., Wattanapongphasuk, S. 2019. Sustainable development facets: factors affecting quality of education. Journal of Security and Sustainability Issues, 9(3), 763-773.

https://doi.org/10.9770/jssi.2020.9.3(3)

JEL Classifications: P46

\section{Introduction}

There unanimous agreement among development economists that education is closely linked with sustainable development (Baltgailis, 2019; Humbatova, Gadim-Oglu Hajiyev, 2019). Education is considered as a main driver of human capital, as it assists in enhancing the productivity of labour, increasing efficiency and increasing the output of economy (Jermsittiparsert \& Sawasdee, 2012; Ahmed, Arshad, Mahmood, \& Akhtar, 2017; Rungsrisawat \& Jermsittiparsert, 2019). According to Akareem and Hossain (2016), education is a key driving force behind economic development of any country.

In almost all of Asian countries, it is believed that education results brining economic prosperity and growth. Due to this reason, it is important to design effective education policy and the key focus must be on teachers, investments and public expenditures (Zeichner \& Bier, 2017). Ansell (2015) stated that nowadays, both public as well as government give much importance to spending on education. People have started giving importance to getting education and there is a high pressure on management of educational institutions to keep the quality 
of education high (Zeichner \& Bier, 2017).

In most of Asian countries, the quality of education is not that much high and there is a need of identifying those factors due to which quality of education gets reduced. The human resource plays a key role in education sector, so this study focuses on analysing the impact of human development and trained teachers on quality of education (Zein, 2016). In addition to this, another key factor which must be studied as a determinant of quality of education is public spending on education (Biersteker, Dawes, Hendricks, \& Tredoux, 2016). It is not always possible to provide quality education to students through having highly skilled and talented teachers, but along with this, there is also a need of high spending from public on education. In order to get high quality education, it is the responsibility of general public to spend considerable amount of money on education of their children. When parents of students make payments and do some expenditure on their children's education, then this helps in enhancing overall quality of education. When public spends on education, then the financial resources provided by them can be used to enhance the overall education system (Birchler \& Michaelowa, 2016; Jabarullah and Hussain, 2019). Previously, there has been no study conducted to examine the combine effect on human development, trained teachers and public spending on quality of education in Asian context. Hence, the current study has been carried out to fill this gap through specifically focusing on Asian context. The study is focused on achieving following objectives;

- To analyze the key influence of human development on quality of education.

- To study the effect of availability of trained teachers on quality of education.

- To examine the key impact of public spending on education on quality of education.

In order to ensure significant contribution towards economic growth, it is important for the government and management of educational institutions to provide high quality education to students. So, this research study is quite beneficial for Asian educational institutions in getting an understanding that how quality of education can be enhanced through giving importance to trained teachers and human capital. Along with this, general public can also understand that how they can get high quality education through giving importance to spending on education. As, no study has been carried out to analyse the relationship between effect of trained teachers' availability, human development as well as public spending on education on quality of education. So, the present research has significant academic implications, in terms of adding value to the literature. The present research project has been divided in to five main chapters; introduction, literature review, methodology, results and analysis and conclusion.

\section{Literature Review}

\subsection{Availability of Trained Teachers and Quality Of Education}

In an education sector, poor quality is resulted because of the presence of untrained as well as uncertified teachers. In Asian countries, there are less number of trained and qualified teachers, particularly in rural areas due to which students are not provided with quality education (Boccanfuso, Larouche, \& Trandafir, 2015). Due to lack of availability of skilled and trained teachers, they do not become able to provide quality education to students. Besides this, untrained teachers also have low motivation level, and they do not fulfill their job responsibilities effectively and efficiently (Zaman, 2015). It is not possible to bring improvement in learning outcomes of students, without giving importance to inadequacies faced by teachers regarding their talent and skills. The training of teachers on regular basis is considered to be highly important, because it helps in enhancing skills and competencies of teachers. In the academic field, there is a need of learning new concepts and things on regular basis, which is not possible without trainings. Hence, trained teachers play an important in ensuring quality of education (Bui \& Nguyen, 2016). It has been argued by (Dutta \& Sahney, 2016) that it is not possible to achieve learning for all children without having professional and talented teachers. The teaching style is also linked highly with talents of teachers. Some teachers do not engage their students during the class and this most commonly results in low learning level of students (You \& Morris, 2016). The successful learning environment requires trained teachers and for ensuring high quality of education, it is important to equip teachers with content knowledge as well as knowledge of learning-promoting teaching methods (Hanushek, 2016). It is important 
to revise teaching methods and make teachers completely trained. Being trained teachers, it is important for them to use innovative methods for enhancing overall quality of education (Tandon \& Fukao, 2015). The success of education depends highly on teachers who are involved in providing education to students. Hence, it is important to have skilled and talented teachers, in order to provide quality education to students (Ganimian \& Murnane, 2016). The skills and competencies of teachers depend on having opportunity of getting trainings on regular basis. The human development is crucial for successful provision of education to students. It is important to analyze the important role played by teachers in enhancing quality of education. It is not possible for an educational institution to provide quality education to teachers, if the teachers engaged in providing education to students are not properly trained. The training of teachers is considered to be highly important for ensuring success of educational institutions. The trained teachers play a key role in providing high quality education to students and they have the capability of making students capable of getting excel in their academic career and this in turn also makes them capable of excelling in professional career (Hakooma \& Seshamani, 2017).

According to the research of Ifa and Guetat (2018), it has been found that teachers are an important facilitator of quality education in all educational institutions. As a result of expanding both primary and secondary level education, it has become highly important to attract and train highly talented teachers. The quality of education gets negatively influenced due to shortage of skilled and competent teachers, particularly in science and mathematics. Ip et al. (2016) claimed that one of the key challenges is that many teachers do not have required knowledge as well as professional environment for performing effectively and efficiently. The professionalism of teachers gets influenced through lack of teaching competencies as well as lack of availability of learning materials. Moreover, Kapur and Perry (2015) found that even if teachers have an ambition of teaching well, then they usually experience different personal limitations, like poor living conditions, due to which their performance at school gets reduced.

H1: There is a significant impact of availability of trained teachers on quality of education in Asia.

Human Development and Quality of Education. In the field of education, the human development is considered to be highly important. It is not possible for teachers to give their maximum input in enhancing quality of education, without giving importance to human development (Landry et al., 2017). Logli (2016) argued that when teachers are not provided with the chance of getting developed, then they most probably prefer to leave the profession. The development of teachers is considered to be highly important for ensuring increased learning of students. The human development of teachers gets affected through providing them training opportunities. According to Sulisworo, Nasir, and Maryani (2017), when teachers get training, then their capability gets enhanced and they prefer to continue this profession for longer time period. With the help of getting training and development opportunities, the skills and competencies of teachers get enhanced and they provide quality education to students. According to Masino and Niño-Zarazúa (2016) training of teachers is highly important in current environment, for coping with the changing demands of profession. Trained teachers get better position of educating the students. The knowledge of a teacher can be improved with the help of training. There can be no underestimation of development and growth of teachers. Training and development is highly important for development of students and this in turn has a positive effect on quality of education (Smith \& Joshi, 2016). It is not possible to improve the quality of education system, without focusing on human development. It has been argued by (Mukminin, Rohayati, Putra, Habibi, \& Aina, 2017) that teachers play an important role within the education system, that without teachers, it is not possible to successfully formulate and implement policies. Human development is important for ensuring high quality of education system. Moreover, (Mundle, 2017) claimed that training of teachers is highly important for those teachers who recently initiate their teaching profession. With the help of human development, the students' learning gets significant enhanced. Students get the most benefit through the human development in the field of education. When teachers are not provided with training, then their skills and competencies level' do not get enhanced and they do not become capable of bringing improvement in students' educational performance (Shimeles \& Verdier-Chouchane, 2016).

H2: There is a significant impact of human development on quality of education in Asia. 


\subsection{Public Spending on Education and Quality of Education}

Public spending is something which is considered to be highly important for bringing improvement within the education sector. When general public spends money on education, then that money can be used within the education sector for the purpose of development (Nowak \& Dahal, 2016). Even though, spending from government is also important, but along with this, there is also a responsibility of public to make financial contribution in order to enhance overall quality of education (Ogundari \& Awokuse, 2018). In addition to this, Phan and Coxhead (2015) argued that public spending on education is important in order to increase the availability of resources. Financial support from general public is important because it can make the resources available, which are required for providing quality education to students.

H3: There is a significant impact of public spending on quality of education.

\section{Methodology}

\subsection{Data}

Being an important step in a research process, data has been collected by the author in a very careful manner. This data has been collected in context of Asian countries such as Japan, China, Indonesia, Vietnam, Hong Kong, Thailand, Singapore and Malaysia. The period for which data has been collected is 25 years. Reliable and authentic databases such as World Bank and Global Economy have been used by the author to ensure quality of data and its results. The variables for which data has been collected include quality of education, human development, public spending on education and trained teachers' availability. Other than these variables, two control variables have also been used in this study i.e. literacy rate and population.

\subsection{Model Specification}

After the collection of data, the next step is to define the units of all the variables that have been involved in the study by the author. In the current study, we are investigating the impact of human development, public spending on education and trained teachers' availability on the quality of education in Asian countries in the presence of two control variables i.e. literacy rate and population. The measurement units and notations of all the above-mentioned variables are given here. The quality of education (EDU) will be measured by the satisfaction level of students. Human development HD will be measured in terms of an index, called as human development index. Public spending on education PSE will be measured in terms of the percentage of spending by people. In the same way, the measurement units of trained teachers' availability TTA are the percentage of total teachers. The first control variable, literacy rate LIT will be measured as the percentage of literate people in the country and finally the measurement units of population POP will be millions. In this way all the variables will be measured and by using them a regression equation has been developed by the author that is given below:

$$
E D U_{i t}=\alpha+\beta_{1} H D_{i t}+\beta_{2} P S E_{i t}+\beta_{3} T T A_{i t}+\beta_{4} L I T_{i t}+\beta_{5} P O P_{i t}+\varepsilon_{i t}
$$

In this equation, EDU represents quality of education, HD shows the term of human development, PSE represents public spending on education, TTA shows trained teachers availability, LIT is the literacy rate, POP denotes population while $\varepsilon_{i t}$ is the term that represents error.

\subsection{Estimation Procedure}

\subsubsection{Panel Unit Root Test}

In the estimation procedure, the first step is to recognize the order of integration of variables as well as the stationary and non-stationary state of the variables. Unit root tests are used for this purpose. The most commonly used unit root tests include ADF, DF, LLC, IPS etc. The importance of these tests is that they provide 
better and accurate results as compared to the traditional unit root tests (Levin, Lin, \& Chu, 2002). They also overcome the size and power related issues of the traditional tests and provide normal and standard distribution of the collected data as well. It must be noted here that unit root tests are based upon the existence of two kinds of hypotheses. The null hypothesis suggests that unit root exists while the data is nonstationary. On the contrary, alternate hypothesis suggests that unit root does not exist while the data is stationary. The results of these tests are evaluated on the basis of acceptance and rejection of these hypotheses. The most important tests in this regard are Levis Lin Chu LLC and Im Pesaran Shin IPS tests. The basic difference among these tests is that LLC shows homogeneous autoregressive process while IPS shows heterogeneous autoregressive system. Based on the type of data collected, the author has employed LLC unit root test in this study, the equation of which is presented below:

$$
\Delta y_{i, t}=a_{i}+\rho y_{i, t}-1+\sum_{J=1}^{p i} a_{J} \Delta y_{i, t-J}+\varepsilon_{i, t}
$$

Here is the difference that $\Delta y_{i, t}$ shows for $\mathrm{i}^{\text {th }}$ country for the specific time period of $\mathrm{t}$.

\subsubsection{Panel Cointegration Test}

After the order of integration and stationarity of the variables has been identified, the author will then apply cointegration tests to the collected data. The basic aim of this test is to find out any cointegrating as well as long run relationship between the variables. Kao and Pedroni are the two most commonly used tests of cointegration. These cointegration tests are further divided into two approaches called as within dimension approach and between dimension approach (Im, Pesaran, \& Shin, 2003). The within dimension approach involves four types of test statistics i.e. v-statistic, rho-statistic, PP-statistic and ADF-statistic. In the very same fashion, between approach also involves three types of statistics i.e. rho-statistic, PP-statistic and ADF-statistic. It must be noted here that PP statistic is nonparametric while ADF statistic is parametric. Just like unit root tests, cointegration tests are also based on null and alternate hypothesis. The null hypothesis in this regard shows no cointegration while the alternate hypothesis shows the presence of cointegration. Based on the acceptance and rejection of these hypotheses, the long run equilibrium relationships can be identified and investigated. As the authors has selected Kao cointegration test to be used in this study, its equation is given as follows:

$$
y_{i, t}=\alpha_{i}+\delta_{i, t}+\beta_{1} X_{1, i, t}+\beta_{2} X_{2, i, t}+\cdots+\beta_{n} X_{n, i, t}+\varepsilon_{i, t}
$$

\subsubsection{Coefficient Estimation Test}

Once the order of integration and cointegration has been investigated in the variables, the author will then use the coefficient estimation techniques to measure the relationship between the variables. For this purpose, ordinary least square approach is usually used but OLS shows some issues such as serial correlation and existence of endogenous variable (Pedroni, 2001). These issues can be resolved by altering OLS and generating two forms from it i.e. dynamic OLS and fully modified OLS (DOLS and FMOLS). The results of these tests have certain coefficients of variables that represent the magnitude of the relationships existing between them. There are two specific conditions, which when fulfilled make these tests provide more accurate and authentic results. The first condition is that there must be only one cointegrating vector present among the variables of first order integration. The other condition in this regard is the there must be no cointegrating vector present among the explanatory variables. As the author has employed DOLS coefficient estimation test, its equation can be presented as follows: 


$$
\hat{\beta}_{F M=}\left(\sum_{i=1}^{N} \sum_{t=1}^{T}\left(x_{i, t}-\dot{x}_{i}\right)^{2}\right)^{-1} \sum_{i=1}^{N}\left(\sum_{t=1}^{T}\left(x_{i, t}-\dot{x}_{i}\right) \widehat{E D U}_{i, t}-T \hat{\delta}_{\varepsilon u}\right)
$$

In this equation, $\widehat{E D U}_{i, t}$ is the transformed variable of quality of education due to endogeneity correction while $\hat{\delta}_{\varepsilon u}$ represents the serial correlation correction by FMOLS.

\section{Empirical Analysis}

\subsection{Results of Panel Unit Root Test}

As discussed in the earlier portion of this study, the first step is to find out the order of integration of the variables of the study. The author had applied LLC unit root test for this purpose and its results are presented in table 1 below. This table shows that there are two different sections for which the test has been applied separately. These sections include level and first difference. The level series shows that all the variables have accepted the null hypothesis but public spending on education as well as population has rejected the null hypothesis. This acceptance of null hypothesis by more variables indicated that in level series the data is nonstationary because the unit root is present. When the variables were first differenced, it can be seen in the table that all the variables have rejected the null hypothesis. This rejection of null hypothesis by all the variables indicates that the data in first difference series is stationary. This shifting from non-stationary to stationary data is based on the concept of first difference. The results got from this test can be concluded by stating that the data is nonstationary in level series while it becomes stationary in the first difference series (see table 1).

Table 1. Panel Unit Root Test - Levin Lin Chu LLC

\begin{tabular}{ccc}
\hline Variable & Level & $1^{\text {st }}$ Difference \\
\hline \multirow{2}{*}{ EDU } & -2.8363 & $-5.5231^{* * *}$ \\
& $(0.334)$ & $(0.002)$ \\
HD & -3.2846 & $-7.2468^{* *}$ \\
& $(0.826)$ & $(0.013)$ \\
PSE & $-4.2864 * *$ & $-12.423^{* * *}$ \\
& $(0.042)$ & $(0.000)$ \\
TTA & -2.0421 & $-11.421^{* * *}$ \\
LIT & $(0.536)$ & $(0.000)$ \\
& -5.6342 & $-13.634^{* *}$ \\
POP & $(0.532)$ & $(0.004)$ \\
\end{tabular}

In this table, * represents that the rejection is one percent significant, ** shows that rejection is five percent significant, $* * *$ shows that rejection is ten percent significant

\subsection{Results of Panel Cointegration Test}

After finding out the stationary and non-stationary state of the collected data, the author then applied Kao cointegration test to find out the cointegrating and long run relationship between the variables in the study. The results of Kao Cointegration test have been presented in the table 2. The results of tests in both within dimension and between dimension approach have been given in the table. It can be seen that in within approach, three out of four statistics have rejected the null hypothesis of no cointegration. In the same way, the between dimension approach shows that two out of three statistics have rejected the null hypothesis of no cointegration. When these results are compiled, it comes out that total of five statistics out of seven have rejected the null hypothesis. As the null hypothesis suggested the absence of cointegrated relationships between the variables, so from the results it can be concluded that cointegrated relationship is present among the variables that have been under study in this research. In addition to cointegrated relationship, the long run equilibrium relationship has also found to be present between these variables. An important point that must be noted here is that ADF 
(parametric) and PP (non-parametric) statistics have more significance in this context which further affirms the presence of significant relationship between the variables.

Table 2. The KAO Panel Cointegration Test

\begin{tabular}{|c|c|c|c|c|}
\hline \multicolumn{5}{|c|}{ Alternative hypothesis: common AR coefs. (within-dimension) } \\
\hline & \multicolumn{4}{|c|}{ Weighted } \\
\hline & $\underline{\text { Statistic }}$ & Prob. & $\underline{\text { Statistic }}$ & Prob. \\
\hline Panel v-Statistic & -2.283472 & 0.7136 & -5.283694 & 0.0000 \\
\hline Panel rho-Statistic & $4.913768^{* *}$ & 0.1638 & 4.162577 & 0.9932 \\
\hline Panel PP-Statistic & $-12.13879 *$ & 0.0000 & -8.842638 & 0.0001 \\
\hline Panel ADF-Statistic & $-4.183691 *$ & 0.0003 & -4.163768 & 0.0003 \\
\hline \multicolumn{5}{|c|}{ Alternative hypothesis: individual AR coefs. (between-dimension) } \\
\hline & $\underline{\text { Statistic }}$ & Prob. & & \\
\hline Group rho-Statistic & $6.286489 *$ & 0.0000 & & \\
\hline Group PP-Statistic & -21.13689 & 0.0000 & & \\
\hline Group ADF-Statistic & $-2.813691 * *$ & 0.0431 & & \\
\hline
\end{tabular}

In this table, ${ }^{*}$ represents that the rejection is one percent significant, $* *$ shows that rejection is five percent significant

\subsection{Results of Coefficient Estimation Test}

Once the order of integration and the long run relationships have been found out, the next step is to measure the relationship that is present among the variable. The author has used DOLS coefficient estimation technique for this purpose. The results of DOLS technique have been given in the table 3 of the study. It can be seen in the table that the impact of human development is significant on quality of education by 5 percent significance level. In other words, quality of education will rise by $22.9 \%$ with increase in one percent of human development. In the same way, the impact of public spending on education has also been found significant is supposed to increase the quality of education by $28.4 \%$ with one-unit increase. The third variable, trained teachers' availability has also significant impact on quality of education and will raise it by $13.6 \%$ with one percent increase. Apart from these variables, the impact of control variable, literacy rate has also been found as significant. From these results, it can be concluded that human development, public spending on education, trained teachers' availability and literacy rate have significant impacts on quality of education.

Table 3. DOLS Regression

\begin{tabular}{ccccc}
\hline Variable & Coefficient & Std. Error & t-Statistic & Prob. \\
\hline HD & $0.227942^{* *}$ & 0.2444 & 3.284689 & 0.0000 \\
PSE & $0.284797^{*}$ & 0.5634 & 4.283694 & 0.0004 \\
TTA & $0.136104^{* *}$ & 0.1334 & 4.297247 & 0.0003 \\
LIT & $0.284697^{*}$ & 0.0032 & 1.497359 & 0.2774 \\
POP & 0.834968 & 0.3532 & 2.358799 & 0.0001 \\
Constant & 0.482319 & 0.6534 & 3.539739 & 0.0002 \\
R-squared & 0.284694 & & & \\
Adjusted R-squared & 0.137684 & & & \\
F-statistic & 32.28369 & & & \\
Prob(F-statistic) & 0.000000 & & & \\
Durbin-Watson stat & 2.247924 & & & \\
\hline
\end{tabular}

In this table, * represents one percent significance level, ** shows five percent significance level 


\section{Discussion and Conclusion}

\subsection{Discussion}

The basic aim behind this study was to find out the impact of human development, public spending on education and trained teachers' availability on quality of education in Asian countries. To achieve this aim, several hypotheses were developed and tested. The first hypothesis was that the human development has significant impact on quality of education. This hypothesis has been accepted by the results and is in accordance with the past study (Havighurst, 1953). The next hypothesis was that public spending on education has significant impact on quality of education. This hypothesis has also been accepted and this result is same as shown by the past study (Ablo \& Reinikka, 1998). The last hypothesis was that the trained teachers' availability has significant impact on quality of education. This final hypothesis has also been accepted by the author on the basis of the results of data analysis. This result is in concordance with a past study (Sindelar, Daunic, \& Rennells, 2004). In the last, the impact of a control variable, literacy rate has also been found as significant in context of quality of education. This same result has been seen in a previous study (Kickbusch, 2001).

\subsection{Conclusion}

Being an important factor of the economic growth of a country, the importance of education has been increasing day by day. In the current study, the impact of human development, public spending on education and trained teachers' ability is being studied on the quality of education of Asian countries. For this purpose, a research was designed, and data was collected from different Asian countries for 25 years. This data was subjected to different tests such as LLC unit root, Kao cointegration and DOLS estimation test. The results of these tests showed that the impact of human development, public spending on education and trained teachers' availability is significant on quality of education. Similarly, the impact of control variable, literacy rate has also been found as significant. There are many theoretical, practical and policy making implications of this study.

\subsection{Implications}

Several theoretical, practical and policy making implications and benefits of this study have been identified. Firstly, it will provide enough literature and information about human development, public spending patterns on education and trained teachers' ratio along with the quality of education. This will help them in their researches and studies. Apart from this, it will also provide guidance to the education department of the country to take certain actions to improve the quality of education in country, which is the need of the hour for almost every country in the world. Finally, it will also provide assistance to the policy making department of the government in order to devise policies that are favorable for education in the country. This will increase the quality of education in the country that will have an ultimate impact on the growth of the country.

\subsection{Limitations and Future Research Indications}

Several limitations associated with this study have been discussed here. In addition, some future research indications and recommendations have also been given for the guidance of the future researchers. First of all, the sample size in this study is very small and it can be increased effectively by other researchers. The data has been collected from Asian countries. Other researchers may consider other countries or regions for data collection purpose. Moreover, the variables that are involved in this study are fixed which may be changed by the other researchers in their studies. The last point is that the future researchers may also apply tests other than those that have been used in this study. In this way, other and future researchers may improve the quality of their researches.

\section{References}

Ablo, E., \& Reinikka, R. (1998). Do budgets really matter? Evidence from public spending on education and health in Uganda. Evidence from Public Spending on Education and Health in Uganda (June 1998). World Bank Policy Research Working Paper (1926). https://doi. org/10.1596/1813-9450-1926 
Ahmed, A., Arshad, M. A., Mahmood, A., \& Akhtar, S. (2017). Neglecting human resource development in OBOR, a case of the ChinaPakistan economic corridor (CPEC). Journal of Chinese Economic and Foreign Trade Studies, 10(2), 130-142. https://doi.org/10.1108/ JCEFTS-08-2016-0023

Akareem, H. S., \& Hossain, S. S. (2016). Determinants of education quality: what makes students' perception different? Open Review of Educational Research, 3(1), 52-67. https://doi.org/10.1080/23265507.2016.1155167

Ansell, N. (2015). Shaping global education: international agendas and governmental power. International Development Planning Review, 37(1), 7-16.

Baltgailis, J. (2019). The issues of increasing the effectiveness of teaching comparative economics, Insights into Regional Development, 1(3), 190-199. https://doi.org/10.9770/ird.2019.1.3(1)

Biersteker, L., Dawes, A., Hendricks, L., \& Tredoux, C. (2016). Center-based early childhood care and education program quality: A South African study. Early Childhood Research Quarterly, 36, 334-344. https://doi.org/10.1016/j.ecresq.2016.01.004

Birchler, K., \& Michaelowa, K. (2016). Making aid work for education in developing countries: An analysis of aid effectiveness for primary education coverage and quality. International Journal of Educational Development, 48, 37-52. https://doi.org/10.1016/j. ijedudev.2015.11.008

Boccanfuso, D., Larouche, A., \& Trandafir, M. (2015). Quality of higher education and the labor market in developing countries: Evidence from an education reform in Senegal. World development, 74, 412-424. https://doi.org/10.1016/j.worlddev.2015.05.007

Bui, T. T. N., \& Nguyen, H. T. M. (2016). Standardizing English for educational and socio-economic betterment-A critical analysis of English language policy reforms in Vietnam English language education policy in Asia (pp. 363-388): Springer. https://doi. org/10.1007/978-3-319-22464-0_17

Dutta, V., \& Sahney, S. (2016). School leadership and its impact on student achievement: The mediating role of school climate and teacher job satisfaction. International Journal of Educational Management, 30(6), 941-958. https://doi.org/10.1108/IJEM-12-2014-0170

Ganimian, A. J., \& Murnane, R. J. (2016). Improving education in developing countries: Lessons from rigorous impact evaluations. Review of Educational Research, 86(3), 719-755. https://doi.org/10.3102\%2F0034654315627499

Hakooma, M. R., \& Seshamani, V. (2017). The impact of human capital development on economic growth in Zambia: An Econometric Analysis. International Journal of Economics, Commerce and Management, 4, 71-87.

Hanushek, E. A. (2016). School human capital and teacher salary policies. Journal of Professional Capital and Community, 1(1), 23-40. http://dx.doi.org/10.1108/JPCC-07-2015-0002

Havighurst, R. J. (1953). Human development and education. https://psycnet.apa.org/record/1953-06438-000

Humbatova, S.I., Gadim-Oglu Hajiyev, N. (2019). The role of spending on education and science in sustainable development. Entrepreneurship and Sustainability Issues, 7(2), 1704-1727. http://doi.org/10.9770/jesi.2019.7.2(63)

Ifa, A., \& Guetat, I. (2018). Does public expenditure on education promote Tunisian and Moroccan GDP per capita? ARDL approach. The Journal of Finance and Data Science, 4(4), 234-246. : http://dx.doi.org/10.1016/j.jfds.2018.02.005

Im, K. S., Pesaran, M. H., \& Shin, Y. (2003). Testing for unit roots in heterogeneous panels. Journal of econometrics, 115(1), 53-74. https://doi.org/10.1016/S0304-4076(03)00092-7

Ip, P., Rao, N., Bacon-Shone, J., Li, S. L., Ho, F. K.-w., Chow, C.-b., \& Jiang, F. (2016). Socioeconomic gradients in school readiness of Chinese preschool children: The mediating role of family processes and kindergarten quality. Early Childhood Research Quarterly, 35, 111-123. https://doi.org/10.1016/j.ecresq.2015.10.005

Jabarullah, N.H. and Hussain, H.I. (2019) The Effectiveness of Problem-Based Learning in Technical and Vocational Education in Malaysia, Education + Training, 61 (5), 552-567.

Jermsittiparsert, K. \& Sawasdee, A. (2012). Formal Education for Non-Thai or Undocumented Person in Thailand amidst the Challenge of Nationalism and Transnationalism: A Case Study of Wat Sirimongkhol School, Samut Sakhon Province. Kasetsart Journal - Social Sciences, 33(2), 203-213.

Kapur, D., \& Perry, E. J. (2015). Higher education reform in China and India: The role of the state. Harvard-Yenching Institute Working Paper Series.

Kickbusch, I. S. (2001). Health literacy: addressing the health and education divide. Health promotion international, $16(3), 289-297$. 
https://doi.org/10.1093/heapro/16.3.289

Landry, S. H., Zucker, T. A., Williams, J. M., Merz, E. C., Guttentag, C. L., \& Taylor, H. B. (2017). Improving school readiness of highrisk preschoolers: Combining high quality instructional strategies with responsive training for teachers and parents. Early Childhood Research Quarterly, 40, 38-51. https://doi.org/10.1016/j.ecresq.2016.12.001

Levin, A., Lin, C.-F., \& Chu, C.-S. J. (2002). Unit root tests in panel data: asymptotic and finite-sample properties. Journal of econometrics, 108(1), 1-24. https://doi.org/10.1016/S0304-4076(01)00098-7

Logli, C. (2016). Higher education in Indonesia: Contemporary challenges in governance, access, and quality The Palgrave handbook of Asia Pacific higher education (pp. 561-581): Springer. http://hdl.handle.net/10125/38825

Masino, S., \& Niño-Zarazúa, M. (2016). What works to improve the quality of student learning in developing countries? International Journal of Educational Development, 48, 53-65. https://doi.org/10.1016/j.ijedudev.2015.11.012

Mukminin, A., Rohayati, T., Putra, H. A., Habibi, A., \& Aina, M. (2017). The long walk to quality teacher education in Indonesia: Student teachers' motives to become a teacher and policy implications. İlköğretim Online, 16(1). https://doi.org/10.17051/io.2017.16366

Mundle, S. (2017). Employment, Education and the State. The Indian Journal of Labour Economics, 60(1), 17-31. http://www.nipfp. org.in/publications/working-papers/1776

Nowak, A., \& Dahal, G. (2016). the contribution of education to economic growth: Evidence from Nepal. International ournal of Economic Sciences, 5(2), 22-41. https://doi.org/10.20472/IAC.2016.023.032

Ogundari, K., \& Awokuse, T. (2018). Human capital contribution to economic growth in Sub-Saharan Africa: Does health status matter more than education? Economic Analysis and Policy, 58, 131-140. https://doi.org/10.1016/j.eap.2018.02.001

Pedroni, P. (2001). Fully modified OLS for heterogeneous cointegrated panels Nonstationary panels, panel cointegration, and dynamic panels (pp. 93-130): Emerald Group Publishing Limited. https://doi.org/10.1016/S0731-9053(00)15004-2/full/html

Phan, D., \& Coxhead, I. (2015). Education in Southeast Asia: Investments, achievements, and returns. Handbook of Southeast Asian economics. Oxford: Routlege.

Rungsrisawat, S. \& Jermsittiparsert, K. (2019). Does Human Capital Improve Health Care Agility Through Health Care Supply Chain Performance? Moderating Role of Technical Orientation. International Journal of Supply Chain Management, 8(5), $792-803$.

Shimeles, A., \& Verdier-Chouchane, A. (2016). The key role of education in reducing poverty in South Sudan. African Development Review, 28(S2), 162-176. https://doi.org/10.1111/1467-8268.12199

Sindelar, P. T., Daunic, A., \& Rennells, M. S. (2004). Comparisons of traditionally and alternatively trained teachers. Exceptionality, 12(4), 209-223.

Smith, W. C., \& Joshi, D. K. (2016). Public vs. private schooling as a route to universal basic education: A comparison of China and India. International Journal of Educational Development, 46, 153-165. https://doi.org/10.1016/j.ijedudev.2015.11.016

Sulisworo, D., Nasir, R., \& Maryani, I. (2017). Identification of teachers' problems in Indonesia on facing global community. International Journal of Research Studies in Education, 6(2), 81-90. https://doi.org/10.5861/ijrse.2016.1519

Tandon, P., \& Fukao, T. (2015). Educating the next generation: Improving teacher quality in Cambodia: The World Bank. http://hdl. handle.net/10986/21002

You, Y., \& Morris, P. (2016). Imagining school autonomy in high-performing education systems: East Asia as a source of policy referencing in England. Compare: A Journal of Comparative and International Education, 46(6), 882-905. https://doi.org/10.1080/0305792 5.2015 .1080115

Zaman, K. (2015). Quality guidelines for good governance in higher education across the globe. Pacific Science Review B: Humanities and Social Sciences, 1(1), 1-7. https://doi.org/10.1016/j.psrb.2016.01.001

Zeichner, K. M., \& Bier, M. (2017). Opportunities and Pitfalls in the Turn toward Clinical Experience in US Teacher Education 1 The Struggle for the Soul of Teacher Education (pp. 197-223): Routledge.

Zein, M. S. (2016). Government-based training agencies and the professional development of Indonesian teachers of English for Young Learners: perspectives from complexity theory. Journal of Education for teaching, 42(2), 205-223. https://doi.org/10.1080/02607476.2 016.1143145 
Sakapas SAENGCHAI is an Assistant Professor of Public Administration of the Faculty of Humanities and Social Sciences, Suan Sunandha Rajabhat University, Thailand. His areas of expertise are Public and Private Administration, and Interdisciplinary Studies in Social Sciences.

Sudarat RODBOONSONG is the Dean Assistant for Research of the Faculty of Humanities and Social Sciences, Uttaradit Rajabhat University, Thailand. Her areas of expertise are Social Development, Community Studies, and Social and Cultural Change.

Samanan WATTANAPONGPHASUK is the Deputy President of the Political Science Association of Kasetsart University, Thailand. Her areas of expertise are Political Science, Local Politics, and Leadership.

Register for an ORCID ID:

https://orcid.org/register

This work is licensed under the Creative Commons Attribution International License (CC BY). http://creativecommons.org/licenses/by/4.0/ 